Western University Scholarship@Western

Centre for the Study of International Economic

Centre for the Study of International Economic

Relations Working Papers

Relations

1982

\title{
The North-South Debate and the Terms of Trade: An Applied General Equilibrium Approach
}

John Whalley

Follow this and additional works at: https://ir.lib.uwo.ca/economicscsier_wp

Part of the Economics Commons

Citation of this paper:

Whalley, John. "The North-South Debate and the Terms of Trade: An Applied General Equilibrium Approach." Centre for the Study of International Economic Relations Working Papers, 8205C. London, ON: Department of Economics, University of Western Ontario (1982). 
ISSN $0228-4235$

ISBN $0-7714-0336-4$

CENTRE FOR THE STUDY OF INTERNATIONAL ECONOMIC RELATIONS

WORKING PAPER NO. 8205C

John Whalley

Departiman: of Economics Library

APR 61982

Univorsity of Western Ontario

THE NORTH-SOUTH DEBATE AND THE TERMS OF TRADE: AN APPLIED

GENERAL EQUILIBRIUM APPROACH

This paper contains preliminary findings from research work still in progress and should not be quoted without prior approval of the author.

DEPARTMENT OF ECONOMICS

UNIVERSITY OF WESTERN ONTARIO

LONDON, CANADA

N6A 5 C 2 
The North-South Debate and the Terms of Trade: An Applied General Equilibrium Approach

John Whalley

Department of Economics

University of Western Ontario

\begin{abstract}
A price endogenous numerical general equilibrium model of world trade is used to analyze terms of trade issues in the North-South debate. 7 blocs are identified, the US, EEC, Japan, Other Developed, OPEC, Newly Industrialized, and Less Developed Countries. The model is benchmarked to a 1977 micro consistent data set. In the central case analysis, protectionist trade policies in the North inflict an annual welfare loss on the South of around 20 billion dollars per year with an associated terms of trade deterioration of around $5 \%$. The welfare cost to the South from Northern trade restrictions is approximately the same order of magnitude as annual North-South aid flows. Protection in the South, the potential terms of trade impacts of immiserizing growth, and changes in foreign aid are also analyzed.
\end{abstract}

January 1982

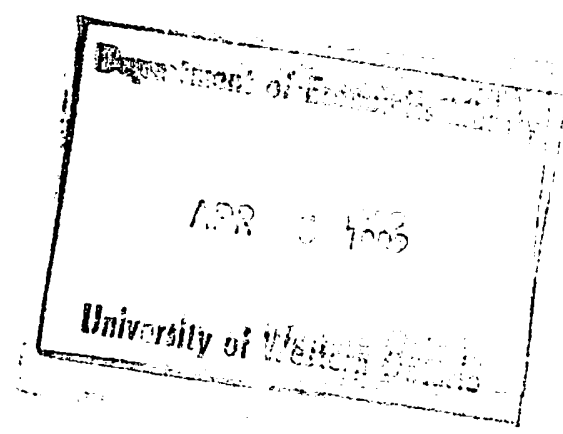

Financial support from the Ford Foundation under their research programme in International Economic order is gratefully acknowledged, as is fine research assistance by Bob Hamilton, Jon Fuller and Randy Wigle. Helpful comments have been received from seminar groups at Southern Illinois, Western Ontario, and the Marga Institute,
Sri Lanka. 


\section{Introduction}

In recent North-South exchanges the terms of trade between developed and developing countries have been a major preoccupation. Discounting naive unequal exchange doctrines, several arguments have surfaced as to why existing North-South arrangements produce terms of trade which are disadvantageous to the South. One is the Prebisch-Singer Thesis (1950), which suggests an inevitable long-term deterioration in the terms of trade of $\checkmark$ IDCs. Another is that protectionist policies in the North adversely impact on the terms of trade faced by the South. Another is the possibility of immiserizing growth which has been prominent in theoretical literature for over two decades. Yet another is the tying of foreign aid such that most of it has to be used to buy imports from the North.

Recent enpirical 1iterature on the North-South terms of trade has concentrated on the first of these arguments. ${ }^{1}$ There is only limited literature on the others, since an explicit numerical price endogenous model of world trade patterns is called for. The multi-country empirical trade models which exist focus almost exclusively on trade between developed countries ${ }^{2}$ and provide little insight into North-South issues.

\section{1}

Spraos (1980), in a recent careful analysis of available statistical evidence, concludes that prior to the Second World War the net barter terms of trade moved against exporters of primary products in favour of exporters of manufactures, al though not by the margin originally suggested by Prebisch. Since the Second World War, it would appear that the terms of trade have moved in favour of primary products (even excluding oil). Michaely $(1980)$, in another recent piece, highlights the dangers of identifying primary exports exclusively as exports of LDCs since developed countries are also major exporters of primary products. He proposes and calculates an income index for each traded commodity at a threedigit SITC level and concludes that the terms of trade of "poor" nations show a clear improvement between 1952 and 1970 .

2

Such as Deardorff and Stern's (1979) model of inter-OECD trade, and Whalley's (1.980) 4 region model of EEC-US-Japanese trade. 
In this paper, results of general equilibrium computations on the North-South terms of trade are reported from an extended version of an earlier world trade model due to Whalley (1980) and used by Brown and Whalley (1980) in their analysis of the Tokyo Round trade negotiations under GATT. The earlier model has been expanded from four to seven blocs with the US, EEC, Japan, Other Developed, OPEC, Newly Industrialized Countries (NICs), and LDCs being separately distinguished as trading areas. ${ }^{1}$ A more detailed presentation of the structure of both 4 and 7 region models will appear in Whalley (forthcoming).

The model incorporates trade protection policies for all blocs, and the data for 1977 trade patterns are used in place of the earlier 1973 trade data. Relative to the earlier 4 region model, an extension to the flexibility of the functional forms used adds generality to the substitution possibilities the model can accommodate. This is used to more adequately incorporate estimates of trade elasticities into the modelling approach. The effects of altering trade policies, changing foreign aid, and immiserizing growth can all be investigated in a North-South context using the model.

The approach adopted parallels that used in other recent applied general equilibrium models, ${ }^{2}$ in that counterfactual equilibrium analysis is performed around a benchmark equilibrium data set to which the model specification is calibrated. 1977 data is used as the benchmark in the present application. The model used incorporates demand and production functions by bloc along with protectionist trade policies modelled in ad valorem equivalent form. The departures from a strict Heckscher-0hlin trade model are the use of the 'Armington' assumption of product heterogeneity by trading area to accommodate cross hauling in observed trade data, and differences in production technology parameters across trading areas. Preferences and production function parameters are separately specified for each bloc; as a result trade is being determined by more than differences in factor endowment $1_{\text {The way individual countries are grouped into these regions is explained }}$
in more detail later.

2 This approac Henderson, and Shoven (1981) Mansur and Whallev (1981) 
ratios as in traditional Heckscher-Ohlin since technology and preferences differ across trading areas.

Results from the calculations indicate that significant annual welfare losses are inflicted on the South through protectionist trade policies in the North. The North, however, also loses from protection in the South. The terms of trade of the South improve by around 5\% if trade protection in the North is removed. Annual welfare gains to the South (NICs and LDCs) from a removal of protection in the North are in the region of $\$ 20$ billion for the central case model specification using 1977 data. This welfare effect is about the same size as the annual aid flow from North to South. Northern losses from their own trade protection are small with the domestic distortion cost being offset by a terms of trade gain. Annual welfare gains to the North from a removal of protection in the South are larger at $\$ 60-70$ billion per year, but are accompanied by significant annual welfare losses to the South ( $\$ 40$ billion) due to an adverse terms of trade effect. Net worldwide gains from a removal of all protection are estimated at $\$ 50$ billion per year. This last figure, however, is still less than 1 percent of worldwide GNP. Additional results are reported from changes in aid arrangements, and the effects of differential growth rates in the world economy. Significant terms of trade effects accompany the tying of aid. Differential growth in the North and South at current rates produce a deterioration in the South's terms of trade which over 10 years is the same order of magnitude as currently attributable to trade protection in the North. The results obtained on the effects of trade protection are mainly accounted for by the combination of levels of protection and the relative sizes of trading areas. Protection in the North (which impacts most harshly on the South through agricultural NTBs and textile restrictions) is milder in terms of ad valorem equivalents than protection in the South, where import substitution policies frequently produce large ad valorem equivalent protection. However, the South (in GNP terms) is much smaller than the North, and North-North trade in manufactures is a dominant feature of world trade. Thus, ad valorem protection at the same rate in both the North and the South would produce different effects because the South is 'small' relative to the North. In the data used, the larger 
protection in the small region and the smaller protection in the large region produce comparable worldwide losses, but with a different geographical composition.

While these findings contain important messages for the emerging North-South debate, they also need careful qualification. The data used, in places, are of poor quality, and several key parameters (especially ad valorem equivalents of protection policies in the South) are little more than stylized best guesses. Income and price elasticities in trade are other key parameters and heavy reliance is placed on a literature search in selecting values. The ad valorem equivalents used to represent protectionist policies are presented in a separate appendix to the paper along with a further appendix summarizing the main sources of 'benchmark' data. Trade elasticities are discussed more fully in the text.

II A General Equilibrium Model of North-South Trade ${ }^{1}$

The general equilibrium model used to analyze North-South trade incorporates seven trading blocs reflecting major participants in world trade. These are the (nine-member) EEC, the US, Japan, Other Developed countries (including U.S.S.R. and Fastern Europe), OPEC, Newly Industrialized countries (NICs), and Less Developed countries (LDCs). The arrangement of individual countries into blocs is given in Table 1 along with the corresponding population and US dollar GNP per capita 1n 1977. Sizes of these blocs in the model reflect the relative US dollar GNP for these areas for 1977 in the World Bank Atlas. The conversion of all data into US dollars using the same exchange rates as in the World Bank Atlas should be noted as an important feature of the data which neglects differences between purchasing power parity and official exchange rates. As noted by Kravis et al (1975), these differences are particularly significant for LDCs.

${ }^{1}$ A more detailed description of earlier versions of the model incorporating only the EEC, the U.S., Japan, and a residual rest of the world is given in Brown and Whalley (1980), and Whalley (1980). 
TABLE

Clagolfication of Countries into Tradins Blocs and Sumary Fentures of Each ${ }^{1}$

\section{Countries Included In Blocs}

\begin{tabular}{|c|c|c|c|c|}
\hline $\begin{array}{l}\text { BLoc 1: } \\
\text { (BEC) }\end{array}$ & $\begin{array}{l}\text { Belgium } \\
\text { Denmark } \\
\text { Franco }\end{array}$ & $\begin{array}{l}\text { Ireland } \\
\text { Italy }\end{array}$ & $\begin{array}{l}\text { Luxemburg } \\
\text { Nether } 1 \text { ands }\end{array}$ & $\begin{array}{l}\text { U.K. Germany } \\
\text { W. Ge }\end{array}$ \\
\hline $\begin{array}{l}\text { Bloc 2: } \\
\text { (U.S.) }\end{array}$ & United States & & & \\
\hline $\begin{array}{l}\text { Bloc 3: } \\
\text { (Japan) }\end{array}$ & Japan & & & \\
\hline
\end{tabular}

Czechoslovakla
E. Germany
Finland
Fr. Polynsa
Gibraltar
Greece
Greenland
Guam
Iran
Iraq
Libya

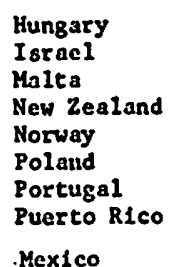

Romailia

Samoa

Spain

Sweden

Switzerland

U.S.S.R.

Virgin Isl.

Yugoslavia

Saudl Arabia

Un Arab Em

Venezuela

(OPEC)

Bahrain

Kuwalt

Bloc 6: Argentina

(NIC) Brazil

Chile

Costa Rica

Cyprus

Ecundor

F1j1

Bloc 7:

Afghanistan

(IDC)

Algerla
Angola
Antigua
Bangladesh
Bclize
Benin
Bhutan
Bolivia
Bot gwana
Burma
Burundi
Camercon
Cape Verde
Ce. Africa
Chad
China
Colombia
Corsoros
Congo
Cuba
Djibouti
Dominica
Doninicn Kp.
Don Kanpuch
Egypt

Fr. Guiana

Hong Kong

Jamalca

Korea

Lebanon

Macao

Malaysia

Nigerla

Onan

Qatar

Martinique

Neth. Ant1l.

N. Cal edonla

Pactfic Island

Panama

Singapore

Suriname

Talwan

Trinidad

Turkey

Uruguay

El Salvador
Ethlopia
Gabon
Gambla
Gliana
Grenada
Guadeloupe
Guatemala
Guinca
Gulnea-Bis
Guyana
Haiti
Jonduras
India
Indonesia
Ivory Const
Jordan
Kenya
Kiribati
Korca
Lacs Fdr
Lesotho
Liberia
Madigascar
Malawi
Maldives

Ma11

Mauritania

Mauritius

Mongolia

Morocco

Mozambique

Namibia

Nepal

New Hebrides

N. Culnea

Nicaragua

N1ger

Pakioton

Paraguay

Peru

Yhilippines

Reunion

RhodesLa

Rwand a

st. Kites

St. Lucia

st. Vincent

Sao Tone

Senegal

Seychelles

Sierra Lcone
Solomon Is.

Somsila

S. Africa

Sr1 Lanka

Sudan

Swaz1land

Syrian A R

Tanzania

Thailind

Togo.

Tonga

Tunista

t'ganda

Upp Volta

Vietnam

Yemen A R

Yemen PUR

Zaire

Zanbia

\section{Populition in billions}

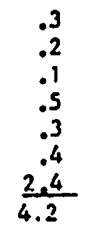

.3
.2
.1
.5
.3
.4
$\frac{2.4}{4.2}$

Bloc 1 (FEC Couritries)

Bloc 2 (U.S.)

Bloc 3 (Japin)

Bloc 4 (Other Developed Countries)

Bloc 5 (OPEC)

Bloc 6 (Newly Industrialized Countries)

Bloc 7 (Less beveloped Countries) TONNL

1977 GNP/Capita
In $\$$ U.S.
6283
8751
6511
3848
$1000.3^{2}$
1306
$\frac{325 . i}{1863}$

1977 GNF

In S bill (U.S.)

$\begin{array}{r}1629 \\ 1897 \\ 737 \\ 2024 \\ 303 \\ 461 \\ 773 \\ \hline 7824\end{array}$

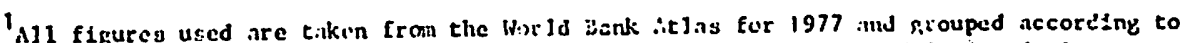
the blocs 11 :ted liese. An inortant polut is that ill coiversions tnto l.S. $\$$ mite in

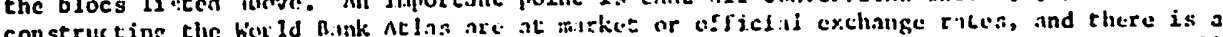

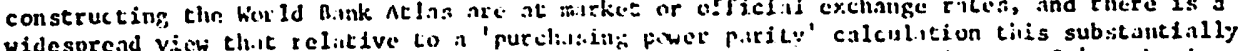

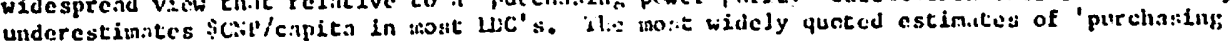
power parity premia are in Kravis et al (1975).

This secningly low figure for Ot'tc arlses from tha inclusion of Nigeria and Mexla" as

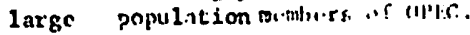


The model considers six products produced in each bloc. These are 1isted in Table 2. Each of the first five goods are internationally traded with an assumed heterogeneity by trading area prevailing across production sources. The sixth commodity is non-traded for a11 blocs. The same commodity classification is used for trade, domestic production, and final demand data, with an approximate concordance used between different classification systems in basic data. The model incorporates less detail than the full version of the four bloc model (Whalley (1980)) which identifies 33 commodities in each bloc. Problems of data availability for all blocs on this classification plus the large dimensionalities involved in solution for a seven bloc model have limited the dimensionality to six products and seven blocs; 42 products in total.

In the model, products are differentiated on the basis of geographical point of production as well as by their physical characteristics, with 'similar' products being close substitutes in demand. Japanese manufactures are thus treated as qualitatively different products from US or EEC manufactures. This 'Armington' assumption of product heterogeneity by area is used both to accommodate the statistical phenomenon of 'cross-hauling' in international trade data and to exclude complete specialization in production as a behavioural response in the model. This structure also enables empirically based import demand elasticities to be incorporated into the model specification.

A schematic flow chart depicting the model is given in Table 3. Production and demand patterns in each of the trading blocs revolve around the domestic and world price systems. Explicit demand functions are used which are derived from hierarchical CES/LES preference functions, and CES functions characterize production sets. Producers maximize profits and competitive forces operate such that in equilibrium all supernormal profits are competed away.

For each product the market price in the model is the price at point of production. Sellers receive these prices, purchasers (of both intermediate and final products) pay these prices gross of tariffs, NTB tariff equivalents, and 
Table 2

\section{Product Classification Used in the Mode1}

SITC Headings

1. Agriculture and Food

$0+1$

2. Mineral Products and Extractive Ores

$2+4$

3. Energy Products (including oil)

4. Non-Mechanical Manufacturing

$5,6,8,9$

5. Machinery and Transport Equipment (including Vehicles)

6. Construction, Services and other

None Non-Traded 


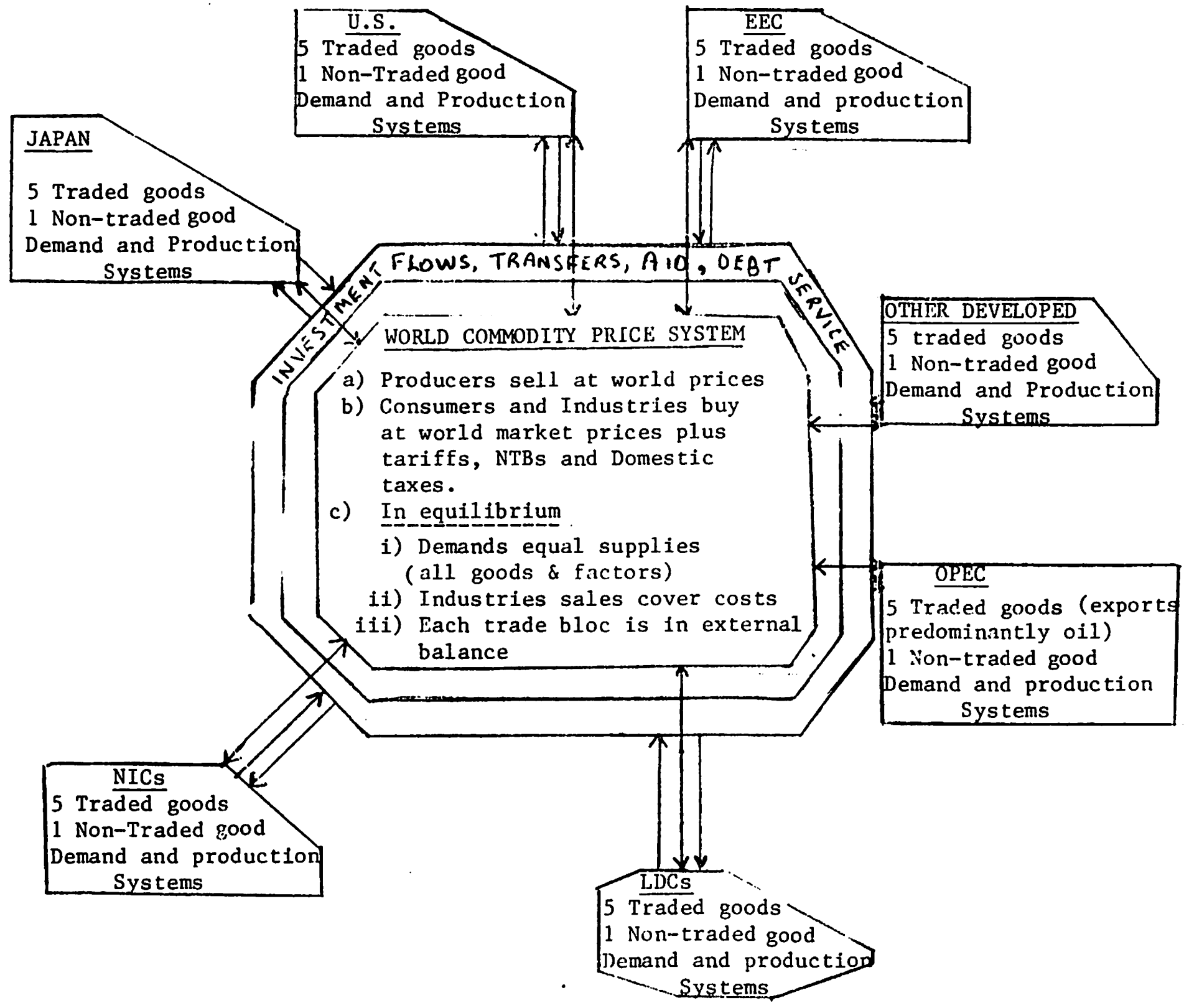


domestic taxes; no transportation costs are considered. Investment flows, interest and dividends, and foreign aid enter the world market system, with the second two of these being treated as income transfers. Foreign investment is treated as purchases of capital goods by agents located in the country of source of capital funds. The difference between investment flows and merchandise trade is that the capital goods acquired are not repatriated to the country of location of the purchaser, but remain in the source country to generate income in future time periods.

An equilibrium in the model is a situation where demands equal supplies for all products and in each industry a zero-profit condition is satisfied representing the absence of supernormal profits. In equilibrium, a zero foreign external sector balance condition (including investment flows, dividends, interest and transfers) applies for each country.

An important feature of the model is the structure of substitution possibilities incorporated through CES functions. The elasticities of substitution in these functions are the parameters which determine price elasticities in goods and factor demand functions. Because of the Armington product heterogeneity assumption these elasticities control import and export demand elasticities for any trading area.

The hierarchical structure of the CES/LES functions used on the production and demand sides of the model is outlined in Table 4. On the production side of the model, each industry has a value-added production function of CES form which specifies substitution possibilities between the primary factor inputs, capital and labour services. No technical change is incorporated and factors are immobile between blocs. 


\section{TABLE 4}

BIERARCHY OF SUBSTITUTION POSSIBILITIES IN WORLD TRADE MODEL

DEMAND

P1nal Demand Functions

In each bloc, a 4 level CES/LES

functional form is used.

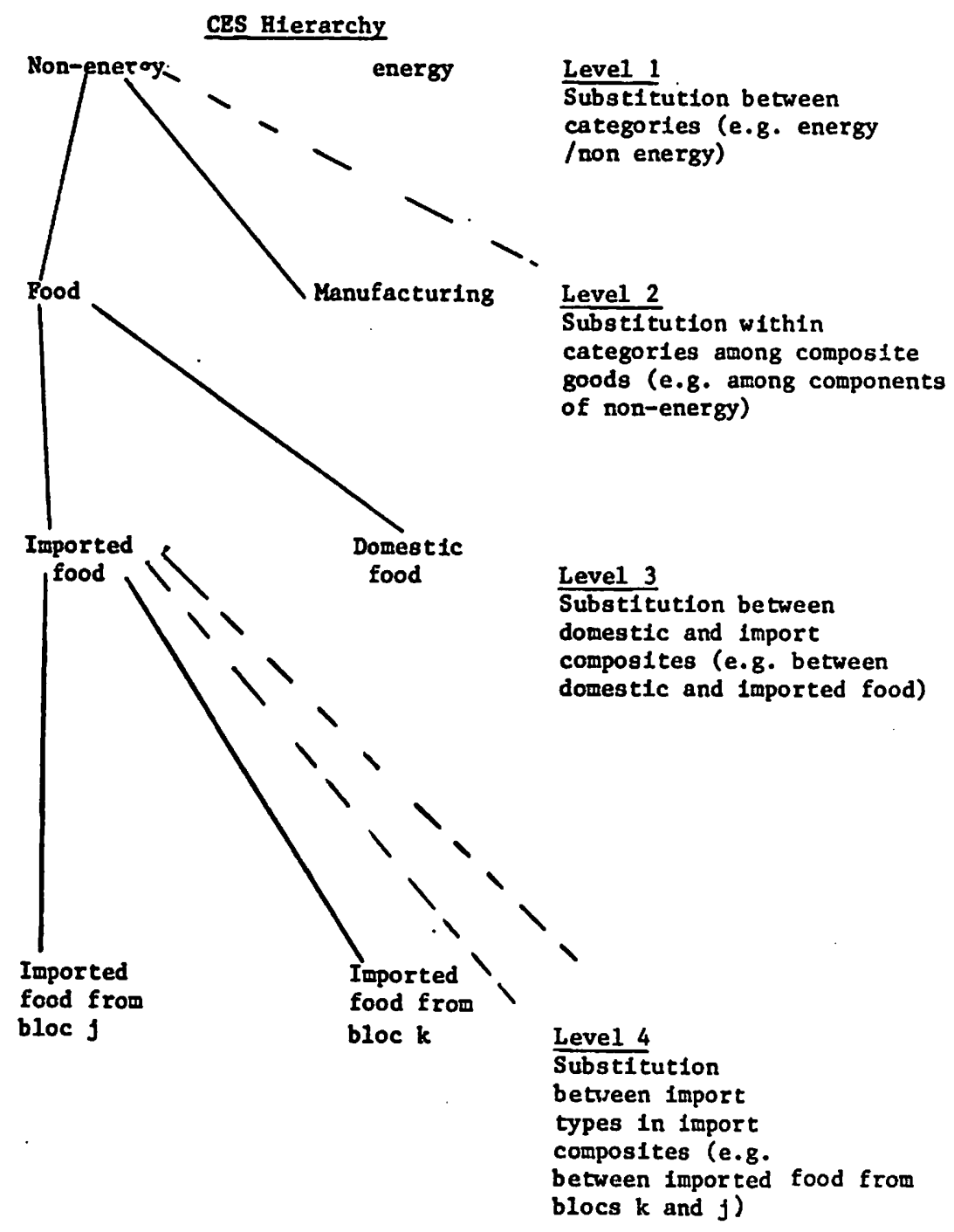

LES HIerarchy

Minimum requirements for each

import composite at level 3 used. These allow Income elasticities for 1mport demands to be different from unity.

\section{PRODUCTION}

\section{Value added Functions}

Each Industry in each bloc has a CES value added function with capital and labour services as primary inputs

\section{Intermediate Subst1tution}

Fixed coefficlent intermediate requirements technology, but with each fixed coefficient expressed in terms of composites only (f.e. a fixed machinery requirement per unit of manufacturing).

Each fixed coefficient input requirement met by cost minimizing bundle of 'domestic and Import composites obtained from CES substitution functions.

CES hierarchy (For each fixed coefficient in terms of composites e.g. machinery requirement per unit of manufacture).

Fixed Machinery Requirement

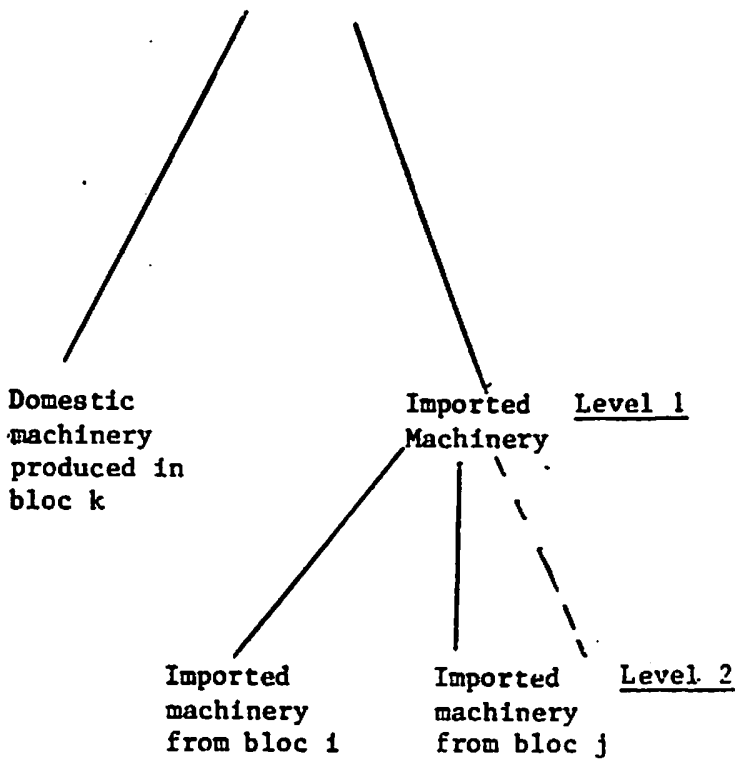


In addition to the CES value-added functions, each industry uses the outputs of other industries (both domestic and imported) as inputs into its own production process. Substitution between intermediate products is allowed while fixed coefficients in terms of composite goods are assumed. Each fixed coefficient in terms of composite goods is a nested CES function with elements of the composite (products identified by geographical point of production) entering as arguments. Substitution occurs between comparable domestic and composite imported commodities at the top level of nesting, with further substitution taking place between import types differentiated by location of production. By way of example, this technology would specify a fixed requirement of steel in the production of a car. The fixed steel requirement could be met by a substitutible mix of domestic and imported steel. Imported steel, in turn, would be a composite of the various types of steel available (differentiated by location of production) with substitution between each. Were the model to separately identify steel as a commodity, the substitution elasticity between domestic and imported steel would be the major determinant of the price elasticity of demand for steel imports. Substitution between types of steel affects the price elasticity of the demand function facing individual exporting blocs.

On the demand side of the model a single set of final demand functions is specified for each of the trading blocs. These demand functions are obtained by maximizing a nestei CF.S/J.F.S utility function. Within this functional form, a hierarchy of substitution possibilities also operates. Elasticities separately control substitution between similar products imported from the various trading areas, and between composites of imports across import sources and comparable domestic 
products. Two ${ }^{1}$ final levels of elasticity values determine substitution between the composite domestic-import products. The LES feature of the demand functions specify minimum requirements for commodities appearing in third level of the nesting structure. These functions differ from those used in Brown and Whalley (1980) in both allowing separate substitution between import types as well as between imports and domestic products, and in incorporating the LES specification.

Use of these nested functions enables empirical estimates of price elasticities in world trade to be incorporated into the model. These values guide parameter choice for inter-nest elasticity values in the CES functions (i.e., between 'similar' products subscripted by location and production). The LES features in the hierarchy allow income elasticities in import demand functions to differ from unity.

Since each bloc generates demands from utility maximization, the market demand functions in the model satisfy Walras' Law. This is the condition that at any set of prices the total value of demands equals the total value of incomes. The incomes of regions are derived from the sale of primary factors owned by each trading bloc plus transfers received,including foreign aid.

\section{An Overview of North-South Trade Policy Regimes}

To help place later results in context, it is useful to provide more detail on the structure of 'North' and 'South' protection and their treatment in the model. The model incorporates trade protection policies in each bloc in ad valorem equivalent form. These policies comprise tariff protection and non-tariff barriers (NTBs), along with certain features of domestic tax policies In the North. Data, especially on ad valorem equivalents of non-tariff barriers,

1

The use of two rather one level nesting above the import substitution stage reflects a general purpose design of the model which is not exploited in the present paper. A future application of the model to world energy trade in an inter-temporal context is planned and the price elasticity of energy demand becomes a key parameter in such an analysis. The need to separately treat energy in such an analysis explains this additional flexibility in nesting. 
is limited and potentially unreliable and the values used along with sources are given in an appendix to the paper. For three of the blocs in the model single countries are involved and the trade policy regime represented by that country alone. For the other four blocs, composites of countries are involved making numerical representation of the trade policy regimes more difficult.

Protection in the North is milder than protection in the South al though substantial variation occurs among the countries which make up the bloc. In the North, post Tokyo Round tariffs on manufactures will average between 6 and 8 percent by 1987, with important IJTBs on agricultural products, textiles and footwear. In contrast, LDCs and NICs frequently have extremely protective tariffs and NTB policies due to import substitution policies. Tariffs are often in the 100 percent range along with quota and other NTB restrictions. ${ }^{1}$

Northern (developed) country tariffs have been substantially reduced during the post-war period through various GATT rounds. Among countries, however, notable differences operate. There is more dispersion in the US than in the EEC tariff, with especially high tariffs on textiles. In addition, smaller developed countries (especially Australia, New Zealand, and Austria) have higher tariffs than larger countries. Low or zero tariffs apply to mineral ores and other resource items. Textiles quotas under the long-term textile agreement supplement tariff protection on these products. Agriculture faces low tariffs but higher non-tariff barriers(particularly through EEC variable levies).

${ }^{1}$ It is worth noting that a few countries in the South have more liberal trade policy regimes. These are typically cases where liberalization has followed or accompanied export-lead growth (such as Chile, South Korea, Taiwan, Malaysia, Sri Lanka). In population terms, these countries form only a small component of the South since China and India between them account for nearly $40 \%$ of world population and around $70 \%$ of the population in the South. 
While some developed country tariff concessions have been negotiated explicitly for less developed countries, they are quantitatively small. As part of the GATT Kennedy Round, a system of generalized preferences (GSP) on 'tropical products' was negotiated, but their quantitative importance is quite limited since textile and agricultural NTB protection in the North remain largely unaffected. The EEC additionally allows certain imports from specified regions (principally Africa and the Caribbean) to enter duty free under the Lomé Convention.

NTBs in the North reflect an assortment of policies which change trade in addition to effects produced by tariffs. A descriptive list of non-tariff barriers would include government purchasing policies, quotas, seasonal restrictions, specific licencing regulations, valuation procedures for tariffs, voluntary export restraints, special import charges (including variable levies in the European Community Agricultural Policy), and health and sanitary regulations. Clearly, some of these are more important than others, and some can be quantified more satisfactorily than others. In terms of impacts on exports from the South, those Northern NTBs with impacts on agriculture, raw materials, and textiles are especially important since these comprise such a significant fraction of LDC exports.

In recent years NTBs have attracted increasing attention, with some arguing that they are a more severe impediment to trade than conventional tariff protection. A number of studies have attempted to classify and describe these barriers, although numerical estimates as to their importance are somewhat sparse. A study by Roningen and Yeats (1976) drawing on UNCTAD documentation provides estimates for France, Japan, Sweden, and the U.S., and a related study by Yeats (1976) examines the role of non-tariff barriers on agricultural products in the EEC. 
Among the countries of the South, the most common form of protection involves high import substitution tariffs, combined with a range of quota and other import restrictions. This pattern is by no means universal with an increasing number of smaller developing countries moving toward liberalized trade regimes, but is sufficiently so that as a typology it serves reasonably wel1.

Import substitution as a policy has its origins in the 1930 s and it is now not uncommon among certain LDCs to find import substitution tariffs as high as 100 percent or more on manufactured imports. Balassa's (1971) classic study of tariff policies in a number of LDCs provides the basic source for estimates used here. In addition to tariffs, quotas operate with either an open or blackmarket for 1icences. A number of studies of Pakistan and Bangladesh report estimates of the market value of licences by product, and a recent study of Bangladesh is used here to give estimates of ad valorem equivalents. Other restrictions also apply to imports. A common supplementary protective device is the use of prior deposit schemes under which a low (or zero) interest deposit with the central bank equal to the value of imports is required 6 to 9 months before import is authorized.

A further feature common in the South is the use of fixed (or controlled) exchange rates, along with foreign exchange rationing. A device often employed is to allow retention of a fraction of foreign exchange earned by exporters as a form of export promotion device.

A reasonable summary of trade protection in the North and South would seem to be that trade protection policies in the North are relatively mild in aggregate, but have sharply discriminatory impacts on particular items of special importance to the South. On the other hand, highly protective trade policies operate in the South. Policies in the North are subject to negotiated reductions under the GATT, while trade policies in the South remain largely unaffected by 
such negotiations.

VI Benchmark Calibration, Elasticities, and Equilibrium Solution of the Model

Once constructed, the general equilibrium model is used for counterfactual equilibrium analysis and $\dot{a}$ flow chart outlining the procedure is given in Table 5 . A worldwide general equilibrium constructed from 1977 data is assumed to hold in the presence of existing trade policies. The model is calibrated to this data set through a procedure which determines parameter values for the model functions consistent with the equilibrium restriction. Counterfactual analysis then proceeds for any specified change; changes in protection, variations in aid arrangements, or differential growth of factor inputs by region (immizerizing growth).

- The calibration procedure involves first constructing a data set for a given year in a form which is consistent with the equilibrium solution concept of the model; a so-called benchmark equilibrium data set. Once assembled, parameter values for equations can be directly calculated from the equilibrium conditions using the calibration procedure described in Mansur and Whalley (1981). The model specification is then capable of reproducing the benchmark data as an equilibrium solution to the model, and comparative statics can be performed with the model by computing new enuilibria for alternative regimes and comparing new and benchmark equilibrium data. The benchmark equilibrium data set constructed for this purpose has the properties of a worldwide competitive equilibrium in that demands equal supplies for all products, no profits are made in any of the domestic industries, and each region is in zero external sector balance.

The micro consistent benchmark data set involves both the domestic and trading activity of each of the trading blocs. Many divergent source materials are required for this purpose and need adjustment for inconsistent classifications and definitions. In addition, further modifications are necessary to mutually adjust the data so that the equilibrium conditions of the model are satisfied. The assembly of data on such a scale inevitably involves a substantial degree of 
MODEL FLOW CHART FOR WORID TRADE GENERAL EQUILIBRIUM MODEL

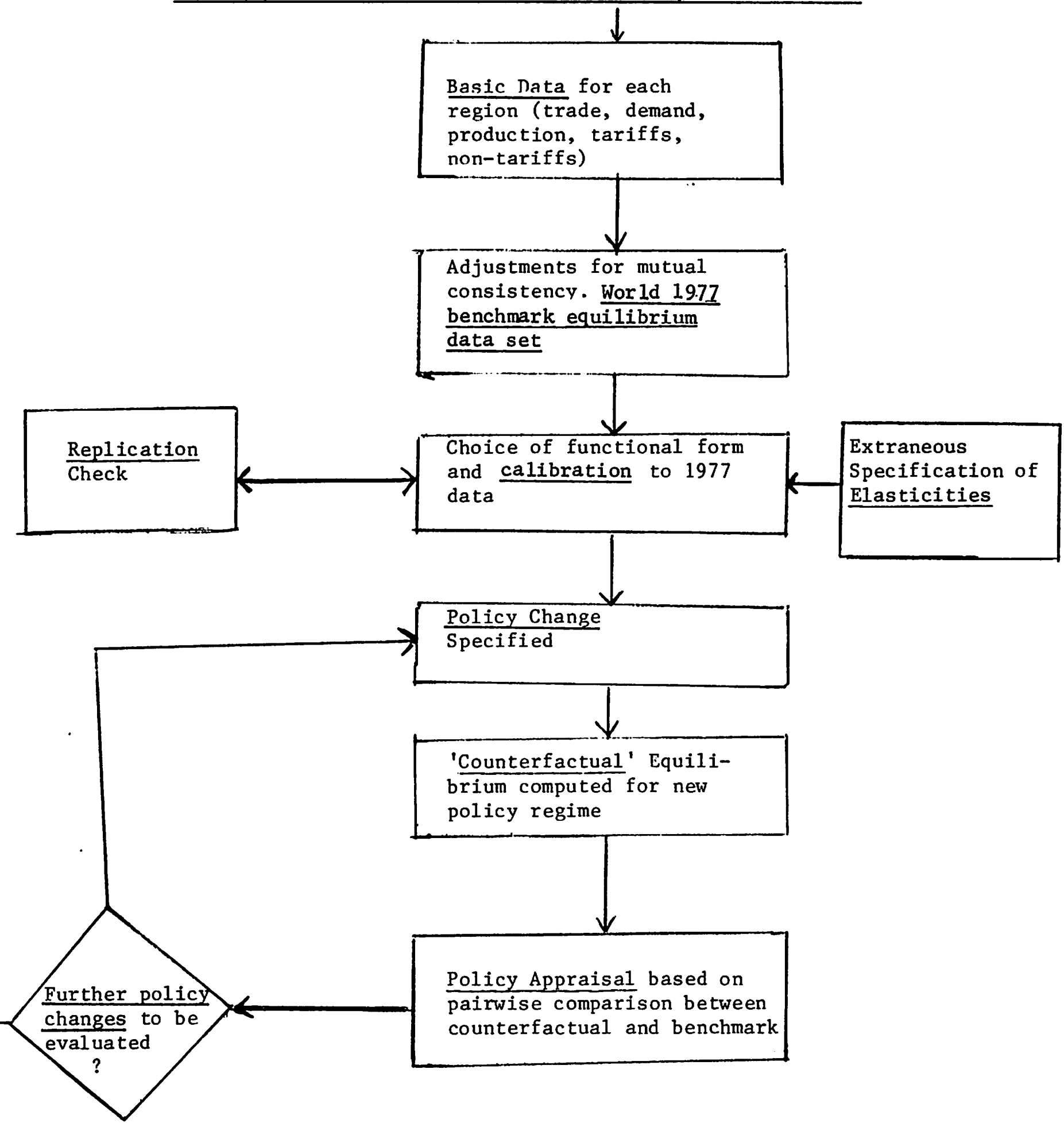


summary judgement and accommodation between data of varying quality. A description of the sources and methods used in assembling the data set for 1977 appears in Appendix B to this paper.

The non-stochastic calibration procedure used in determining parameter values involves taking equilibrium conditions and solving for parameter values from equilibrium observations. Because of the CES/LES functional forms used, this procedure requires more than the benchmark equilibrium data set. This information requirement is met by specifying elasticities of substitution and minimum requirements in the functional forms. ${ }^{1}$ once these are chosen, demand functions are solved for share parameters consistent with both equilibrium prices and quantities. On the supply side, cost functions are similarly solved for share and unit parameters consistent with equilibrium prices and input use by industry.

Not surprisingly, the values chosen for substitution elasticities have a substantial impact on the results produced by the model. An especially important set of parameters is the substitution elasticities which determine implicit trade elasticities. Because of their special importance for the results presented later, a fuller discussion is provided of the choice of these values. In Table 6 1iterature survey import price and income elasticities and export price elasticities are reported by trading area, based on a number of literature sources. These (predominantly time series) estimates provide the basis for the selection of trade substitution values in the model.

If Cobb-Douglas functional forms are used for demand functions, the exponents in the Cobb-Douglas functions are given directly by the expenditure shares in benchmark data. With CES/LES functions, more information is needed and extraneous values of substitution elasticities and minimum requirements are needed prior to the application of this procedure. 
Table 6 suggests import price elasticities in the neighbourhood of unity and export price elasticities a little higher. Income elasticities of import demand are in the region of 1.5. The OPEC income elasticity of 0.24 is selected from a single set of estimates for Venezuela. Import prices elasticities for developed countries reflect the Stern, Francis, Schumacher (1976) compendium of trade elasticities, and estimates for developing countries are due to Khan (1974).

These ranges reflect the current consensus on trade elasticities, al though their use should not pass without comment. Several authors have raised difficulties with time series estimation of trade elasticities. Orcutt (1950) long ago suggested specification bias, and Kemp (1962) suggested that errors in measurement of import price indices may lead to a bias toward unity. Trade researchers frequently argue that time series estimates are too low, and some (such as Balassa and Kreinen (1967)) have used significantly higher values based on 'so-called' tariff elasticities. In spite of these reservations, estimates of these type are still commonly employed and are also used here. Time series estimates provide the main source for the compendium of trade elasticities compiled by Stern, Francis, and Schumacher (1976). Recent estimates for the US, EEC, and Japan by Stone (1981) provide detailed product by product estimates and are approximately consistent with the values reported in Table 6 .

The elasticity configuration used to represent the central case specification of the model is reported in Table 7. Substitution elasticities between comparable domestic and foreign goods in both final demands and intermediate production are set at own price elasticities of import demands by bloc reported in Table 6. For any bloc, the same values are used for all products. Elasticities between import types in both final demand and intermediate substitution are all set at 1.5. This parameter determines export price elasticities for exporting blocs. No simple method is available to relate bloc-wide estimates for export price elasticities to the substitution 
Table 6

IIterature Survey Trade Klasticities Used In the rodal

Trading Area

EEC

US

JAPAN

OTHER DEV.

OPEC

NIC

LDC

\section{'Central Tendancy' \\ Import Price}

Elasticities

$-.91$

$-1.66$

$-.78$

$-1.02$

-0.89 (Venezuela)

$-1.38$

$-1.28$

\section{'Central Tendancy' \\ Import Income \\ Elasticlties}

1.77

1.51

1.23

1.41 (Portugal)

0.24 (Venezuela)

1. 29 (Turkey)

1.43 (Ind 1a)
'Central Tendancy'

Export Price

Elasticities

$-1.14$

$-1.41$

$-1.25$

$-1.26$

-0.83 (Venezuela)

- 1.41 (Turkey)

- 1.82 (Pakistan)

\section{Sources: EEC}

US

JAPAN

OTHER DEV

OPEC

NIC

LDC
- Welghted average over country 'best guess' estimates suggested by Stern, Francis and Schumacher (1976) from their Jiterature survey, and Houthakles/Magee (1969)

- Stern, Francis and Schumacher 'best guess' plus Houthakker/Magee

- Stern, Francis, and Schumacher 'best guess' plus Houthakker/Magee

- Arithmetic average over EEC, US, and Japan, plus Houthakker/Magee

- Estimates for Venezuela due to Khan (1974)

- Estimates for Uruguay, Colombia, Brazil, Argentina, and Turkey reported by Khan (1974). Weisskoff (1979), and Taplin (1974)

Estimates for Banglasesh, Sri Lanka, Phillipines, Pakistan, Morocco, Ghana, Indla, and Ecuador due to Khan (1974), Nguyen and Bhuyan (1977), and Houthakker/Magee (1969) 
elasticities in importing blocs in the mode1, since blocs typically

import from all (or most) sources. This explains the common value of 1.5

with sensitivity analysis around this specification. Import income elasticities are all set at unity in the central case with sensitivity analysis in later cases to reflect the suggestion from Table 5 of values above unity. Unitary income elasticities correspond to the case of homothetic preferences. Other elasticities are: (i) Cobb-Douglas at higher levels for substitution between composite goods in demand; and (ii) literature based estimates for capital labour substitution in the CES value added functions. 1

The parameters used in the model are not separately calibrated to estimates of import and export supply elasticities. Goldstein and Kahn (1978) report high export supply elasticities for some countries from their simultaneous estimation of export demand and supply functions. Effectively infinite supply elasticities for Japan are found, values in the neighbourhood of 5.0 are found for the US and West Germany, and values closer to 1.0 for smaller economies such as Belgium. A difficulty in relating such estimates to the specification of general equilibrium trade models is that there is not a supply function for exports as such in these models but a supply function for exportables. The market is in the homogeneous product which is consumed both domestically and abroad, rather than in the product consumed abroad alone. Trade models with linear homogeneous production will yield partial equilibrium supply elasticities for exportables which approach infinity in the sense that profit maximizing producers

The survey by Caddy (1976) provides the main source for these estimates. An average over the estimates reported by Caddy is used for each industry in the model . with use of 'best guesses' where industry estimates do not occur in Caddy. The values adopted are the same for each trading area, and are on average below unity reflecting the preponderance of time series estimates (as opposed to cross section) in Caddy. The problems of reconciliation between time series and cross section estimates are discussed in Berndt (1976). 


\section{Table 7}

Elasticity Configuration in Central Case

Demand

1) Top level elasticities (substitution between categories) set equal to 1.0 (Cobb-Douglas) in all blocs.

2) Second level elasticities (substitution within each category) set equals to 1.0 (Cobb-Douglas) in all blocs.

3) Third level elasticities (substitution between comparable domestic and import composites) set equal to literature survey import price elasticities - within any bloc the same value is used for all commodities.

4) Fourth level elasticities (substitution between import types in forming import composites) set equal to 1.5 -

5) Income elasticities for import demand functions set equal to unity - LES functions have zero minimum requirements.

\section{Production}

(1) CES value added functions weighted average of industry estimates from.Caddy (1976) -

- same values used in each trading bloc -

(2) Elasticities in CES intermediate coefficient funetions.

(a) elasticities between comparable domestic and import composites - set equal to import price elasticities in Table 5.

(b) elasticities between import types in forming import compositesall set equal to 1.5 in all blocs- 
who face equilibrium prices for which zero profit conditions hold are indifferent as to what quantity they sell. To the extent that one is willing to interpret estimated supply elasticities in this way, no necessary contradiction exists between the present model and the large estimated values reported.

Once specified, the model is solved for a new general equilibrium for a policy or other change using a Newton method involving an estimate of the Jacobian matrix of excess factor demands and government budget imbalances. This method works more rapidly than Scarf's algorithm ${ }^{1}$ or the restart methods of Merrill and others for the type of general equilibrium problems solved with this model. Although there is no ex ante argument of convergence with the Newton method used it has been successful in implementation. A further point is that because of the complexity of the model, no guarantee of uniqueness of equilibrium is available. With numerical solution of similar models some experimentation has been done in displacing equilibria once found and checking that these are returned to, and also in approaching equilibria from different points and at different speeds. None of these tests has revealed a situation of non-uniqueness al though it is certainly not excluded. 2

${ }^{1}$ See Scarf (1973) and the extension to international trade models with tariffs by Shoven and Whalley (1974).

2 Kehoe (1980) has shown that for general equilibrium models with production an index can be associated with any equilibrium which is either +1 or -1 with the property that the sum of the indices will be +1 . There is a suggestion that -1 equilibria are unstable. In a simple numerical example involving four commodities, four households with Cobb-Douglas demands, and a small number of activities, Kehoe illustrates a case of non-uniqueness for what does not seem to be in any way an extreme or implausible specification. In this example, the equilibrium prices are widely separated between the equilibria, suggesting that non-uniqueness may not be as unlikely an occurrence as the numerical ad hoc tests seem to indicate. In a more recent paper Kehoe (1981) suggests that for models with two factors of production, uniqueness may be more likely to hold. 
VII. Results from Counterfactual Equilibrium Calculations

In this section results are reported from a number of model calculations as to the impacts of changes in trade protection in the North and South and other variations in model specification. Two types of result are highlighted; the impact on the terms of trade by bloc, and the annual welfare gain or loss to each trading area from the policy or model change.

For each experiment, changes in the net barter terms of trade are calculated for each bloc in its trade with all others. The net barter terms of trade is simply a quantity weighted price index giving the relative price between a composite of imports and a composite of domestic products (exports). Alternative quantity weights are available; those associated with the benchmark equilibrium or the new equilibrium; quantities imported, quantities exported; quantities consumed, or quantities produced. There is substantial discussion in the literature as to the relative merits of alternative sets of quantity weights; here quantities produced in the benchmark equilibrium are used.

To measure the annual welfare impacts of trade policy changes we use Hicksian equivalent variations (EV's). Hicksian compensating variations measure the dollar amount needed to compensate an agent for a change which has occurred; with Hicksian equivalent variations, the dollar amounts equivalent to the effects induced by change are calculated. Equivalent variations use 'old' equilibrium prices in the calculation while compensating variations use 'new' prices. EV's are computed by trading area as measures of annual welfare impacts, with the sign convention that a positive measure indicates a welfare improving change. The arithmetic sum of EV's is reported as the measure of the worldwide welfare gain or loss from a policy change. Aggregation difficulties arise with such a measure (see Boadway [1974]), but in the absence of other simple alternatives this measure is nonetheless used. Primary stress is placed on equivalent variations since the 
equivalent variation calculation uses old period prices and pairwise comparisons between new and benchmark equilibria which produce estimates of welfare effects all use the same set of prices. This same justification for using EV's is offered by Kay (1980).

In Table 8 the results of computations using the central case specification of the model are reported for three policy variations: the abolition of tariff and non-tariff barriers in the North (blocs 1-4); the South (blocs 5-7); and the world (a11 blocs), respectively.

In the case where the abolition of tariff and non-tariff barriers occurs in the North, a significant annual welfare gain is produced for LDCs and NICs of approximately $\$ 20$ billion. These two blocs account for the majority of the worldwide welfare gain listed. These welfare changes are collinear with the terms of trade effects, with the terms of trade of NICs and LDCs improving by 5-6 percent.

An interesting aside is that the annual gain to the South from removing protection in the North is approximately equal to the annual aid flow from the North to the South. A cynical view of the North-South aid mechanism would therefore be that the North gives approximately $\$ 20$ billion per year to the South which is then offset by a terms of trade loss inflicted through protectionist policies imposed in the North. Such a finding clearly supports the concerns stated by the South in the North-South debate that potential gains are available to the South from the removal of protection in the North. This gain of $\$ 20$ billion is in the region of 2 percent of GNP for the NIC/LDC group.

The effects of trade protection in the North, however, must be considered along with trade protection in the South where ad valorem equivalent protection is significantly higher. Removal of protection in the South yields substantial gains to the North and losses to the South. The worldwide gain from removal of Southern tariff and non-tariff barriers is in the region of $\$ 17$ billion but an approximately $\$ 50$ billion loss is inflicted on the South along with a $\$ 70$ billion gain to the North. This result dramatizes a feature 
TABLE 8

Annual Welfare Impacts of Trade Policy Variations in the Model

i) 'Central Case' model specification - EV's, bill \$ 1977

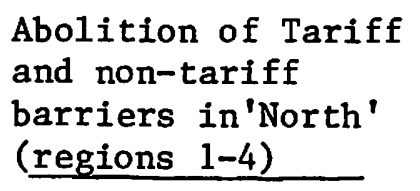

EEC

US

JAPAN

OTHER DEV.

OPEC

NIC

LDC

TOTAL

$$
-0.59
$$$$
-0.24
$$

0.03

0.78

1.76

9.28

10.43

21.45

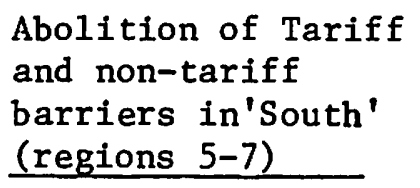

Abolition of Tariff and non-tariff (regions 5-7)

33.53

13.04

16.67

2.67

7.39

$-31.07$

$-24.70$

17.53
Abolition of Tariff and non-tariff barriers in all regions

30.49

11.29

15.46

2.27

8.30

$-22.28$

$-14.96$

30.57

ii) Terms of trade impacts for the same cases (tve indicates gain) $\%$ change in terms of trade

$\begin{array}{llrr}\text { EEC } & -2.4 & +16.9 & +14.1 \\ \text { US } & -2.0 & +6.3 & +4.9 \\ \text { JAPAN } & -2.5 & +23.6 & +20.5 \\ \text { OTHER DEV. } & -3.1 & +5.3 & +2.7 \\ \text { OPEC } & +1.2 & +4.7 & +6.2 \\ \text { NIC } & +5.7 & -26.5 & -21.9 \\ \text { LDC } & +5.3 & -25.7 & -21.2\end{array}$


neglected in the North-South debate, where the focus has been almost exclusively on ways of improving the position of the South. It would seem on the basis of these results that a possible response by the North to pressure from the South to liberalize is that trade 1iberalization in the North should be accompanied by some liberalization in the South.

These results also argue that as a bloc the South will not gain by liberalizing trade policies in spite of the arguments often made by development economists that trade liberalization is a desirable policy option for many, if not most, LDCs. While individual countries in the South may well gain from trade liberalization if the bloc as a whole does not liberalize, simultaneous moves by all countries in the bloc to liberalize will be detrimental to the South because of the adverse terms of trade impacts.

The last case reported in Table 8 involves the joint abolition of all tariff and non-tariff barriers in all blocs. Here the worldwide gain of $\$ 30$ billion is smaller than the sum of the gains reported in the sub cases in Table 8 . The finding is thus that in terms of worldwide protection, the South is the significant gainer as regards terms of trade impacts due to the higher protection which prevails in their bloc. This more than offsets the size differential between blocs.

Because of the key role played by elasticities in the calculations reported in Table 8, a number of sensitivity analyses on these cases have been performed which are described in Table 9. The sensitivity variations are split between cases 1-5, all of which refer to removal of tariffs and non-tariff barriers in the North (blocs 1-4), and cases 6-10 which analyze the removal of tariff and non-tariff barriers in the South (blocs 5-7). The first two sensitivity variations refer to changes in import price elasticities (cases 2 and 7 ) and changes in export price elasticities (cases $3-8$ ). The other cases involve variations in income elasticities. 


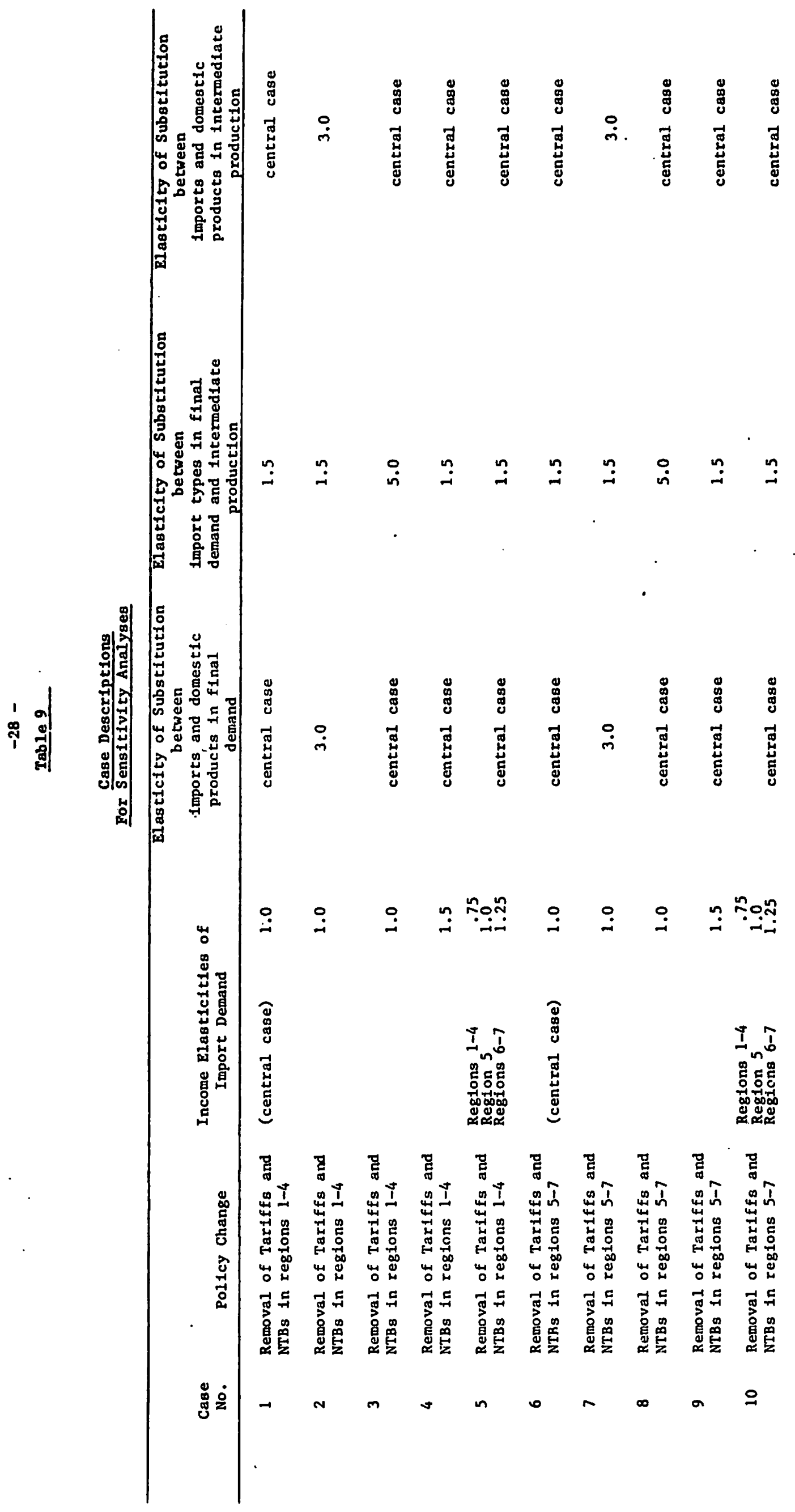


Table 10 reports the sensitivity analysis results. As might be expected, variations in elasticity values significantly affect the estimated impacts of policies. In case 2 terms of trade effects associated with the abolition of tariff and non-tariff barriers in the North are substantially strengthened by raising import price elasticities in all blocs. In Case 3, the terms of trade effects are weakened by raising export price elasticities and gains from the removal of protection accrue to the North rather than the South. Comparable sensitivity findings occur in cases 7 and 8 , although the weakening of the terms of trade effect in case 8 is sufficient to give the LDCs a gain from removing their tariff and non-tariff barriers. The differential behaviour of the model from varying import and export price elasticities in this way is due to the large trade volume effects associated with the first type of change, but small trade volume effects with the second. With export price elasticity variations, the elasticity faced by any one bloc is raised by allowing more substitutibility between import types. The substitution elasticities between import composites and domestic products remain the same, accounting for little change in trade volumes. Variations resulting from varying income elasticities are less significant with the most significant changes occurring for the EEC in cases 5 and 10 .

Table 11 reports cases where the terms of trade effects associated with differential growth rates in North-South trade are analyzed using the model. These analyses are motivated by the literature on immizerizing growth (Bhagwati 1958). The annual growth rates by bloc taken from the World Bank Atlas are reported, with the North on average being slower growing in GNP terms than the South. The rate of growth of GNP in the South does not, however, imply higher growth of GNP per capita since population growth in the South is significantly higher. These growth rates are taken as rates of growth of both factor endowments in each bloc even though growth may not in practice be balanced; this treatment corresponds to that used in theoretical literature on immizerizing growth. 


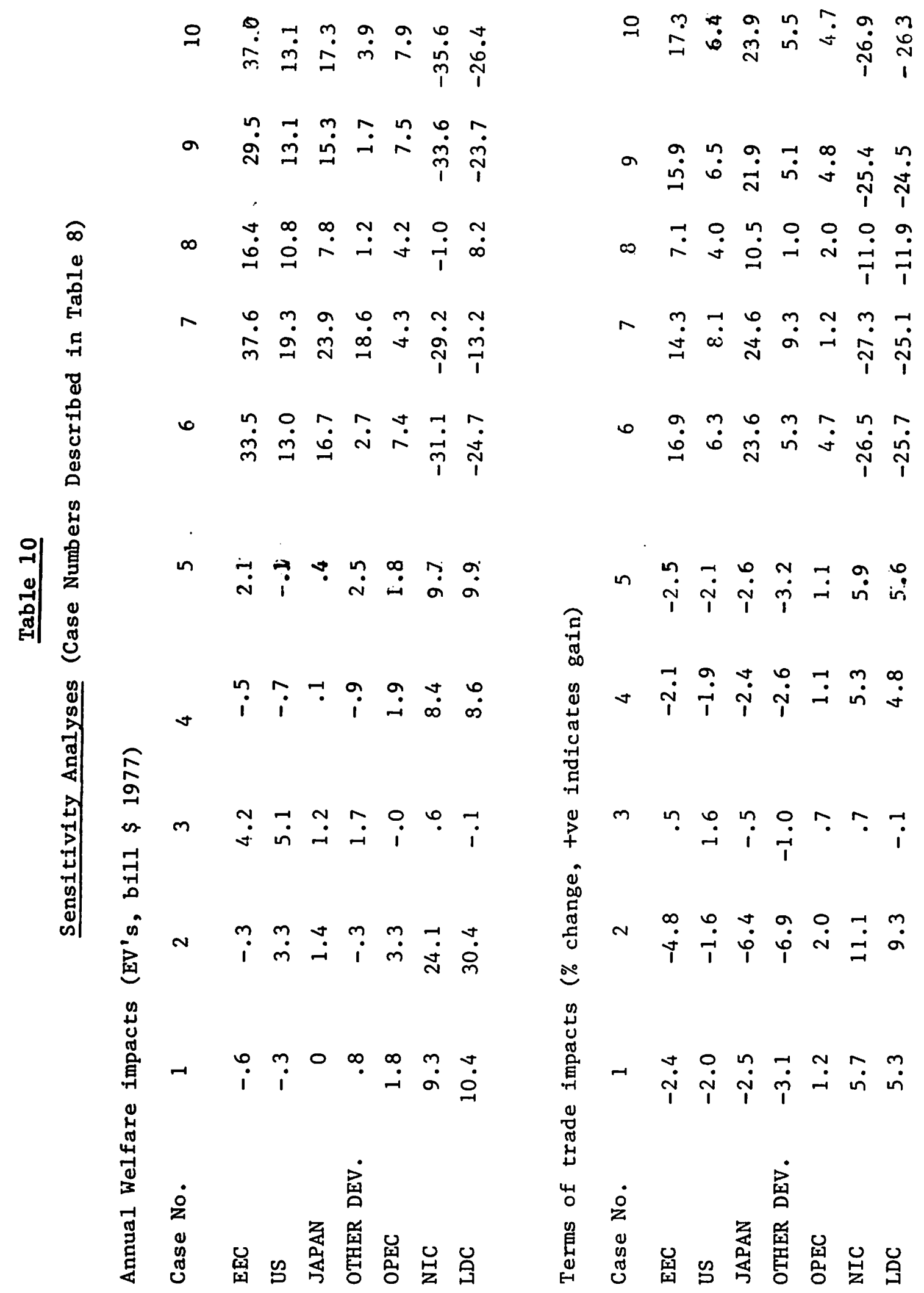




\section{TABLE 11}

Differential Growth Rates and North-South Terms of Trade

Annual GNP growth by bloc computed from World Bank Atlas

(10 year averages - 1968-78)

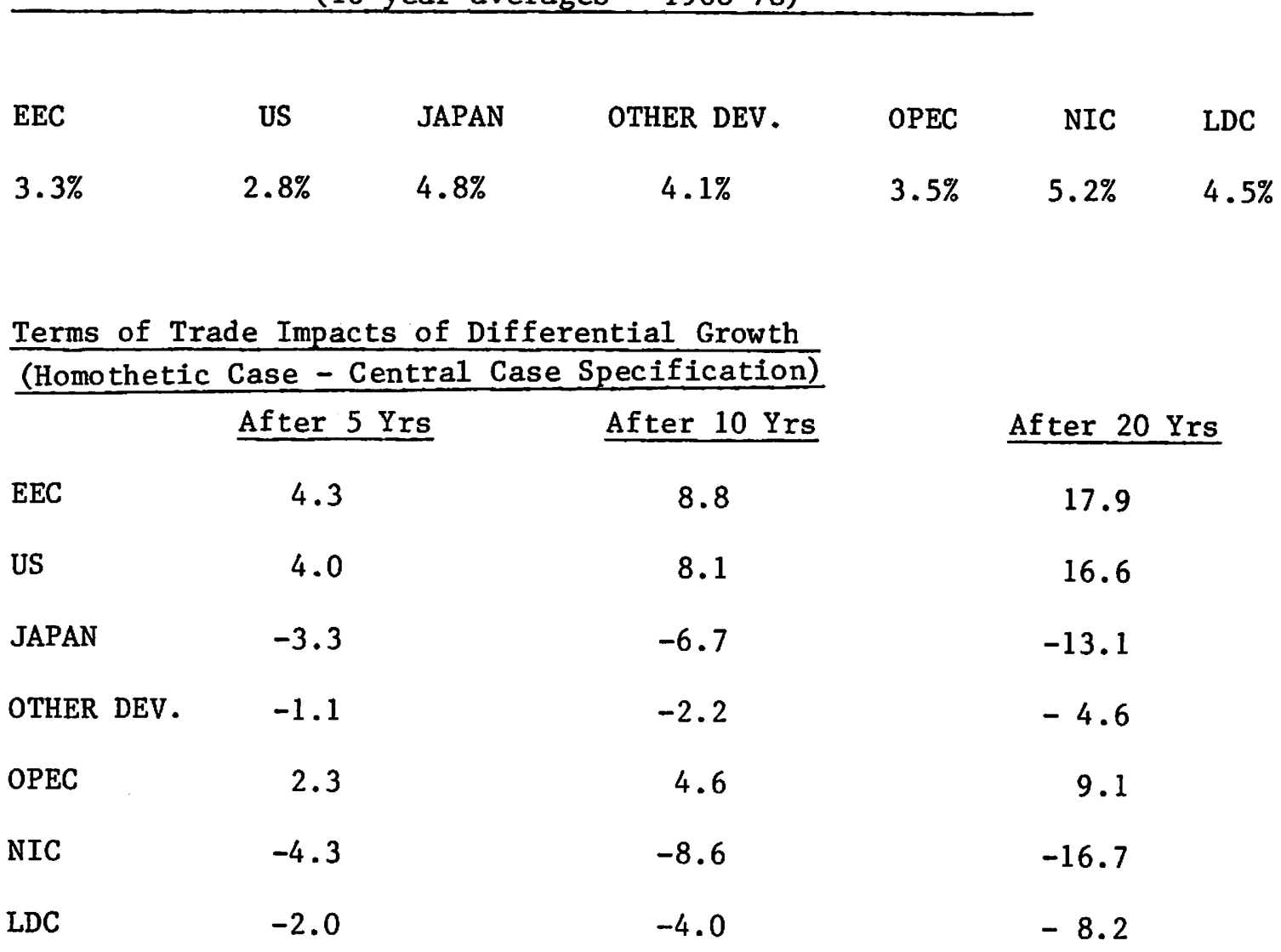

Non-Homothetic Cases (terms of trade impacts after 10 years)

\begin{tabular}{|c|c|c|c|c|c|}
\hline Import Income & B1des & $1-4$ & 1.5 & .5 & .75 \\
\hline Elasticities* & Blocs & $6-7$ & 1.5 & 1.5 & 1.25 \\
\hline EEC & & & 8.2 & 8.9 & .8 .8 \\
\hline US & & & 7.8 & 8.3 & 8.2 \\
\hline JAPAN & & & -5.9 & -6.7 & -6.7 \\
\hline OTHER DEV. & & $\therefore$ & -2.2 & -2.1 & -2.1 \\
\hline OPEC & & & 4.5 & 4.6 & 4.6 \\
\hline NIC & & & -8.4 & -8.8 & -8.7 \\
\hline LDC & & & -4.0 & -4.2 & -4 \\
\hline
\end{tabular}

* The income elasticity in OPEC is set at unity. 
As is to be expected from the literature discussion of this issue, the blocs which are relatively fast growing suffer a deterioration in their terms of trade. The impact of differential growth on the terms of trade is reported in Table 11 for both homothetic and non-homothetic preference cases. In the homothetic cases, after ten years the EEC and the U.S. have an 8 percent appreciation of their terms of trade with a deterioration in the terms of trade of the South of approximately 6 percent. This ten year deterioration is approximately equal to the adverse move in Southern terms to trade resulting from protectionist trade policies in the North. Thus 10 years differential North-South growth appears roughly comparable in significance for the North-South terms of trade to the annual terms of trade effects of protection in the North.

Results from non-homothetic cases are also reported. These are partially motivated by the literature indications that income elasticities in world trade exceed unity and partially by the rationalization for the 'Prebisch-Singer' thesis that with differential income elasticities in import demands there will be an inevitable deterioration in the terms of trade of the South. The results produced from these cases are little different from the homothetic case, although the seemingly counter-intuitive finding is reported that with higher import income elasticities in all regions terms of trade effects from immiserizing growth are weaker. This result is due to the Engel aggregation condition that demand functions satisfy. Since the weighted sum of income elasticities across domestic and imported goods must be unity in all blocs, the smaller import expenditure share in the South produces higher income elasticities for own products than in the North. This partially offsets the terms of trade effect from immiserizing growth. The terms of trade effects are unambiguously strengthened where import income elasticities exceed unity only in the South. 
In Table 12 model results from changes in foreign aid arrangements are reported. The changes considered are first an abolition of annual NorthSouth aid flows, and secondly a doubling of the same flows. The model treats all aid as untied cash transfers due to the complexities of incorporating partial or full tying of aid into the general equilibrium framework used. This explains the striking conclusion from these calculations that substantial secondary burdens with aid are involved for donor countries. The reas on for this result, however, is interesting since it suggests that untying foreign aid would be a major source of gain for LDCs. In the model, recipients of aid use most of the transfer of cash to purchase their own products rather than purchase imports from aid donors. This occurs because the expenditure patterns by product within all blocs are dominated by purchases of own products. As a result, the secondary burden of aid borne by donors is substantial. In the case of an abolition of annual aid flows from the North to the South, the loss to IDCs is $\$ 45$ billion, whereas the direct cash loss from the aid abolition is only $\$ 20$ billion. Correspondingly, a doubling of aid flows from the North to the South gives increases in welfare of LDCs by $\$ 40$ billion, whereas the incremental aid flow would only be $\$ 20$ billion. The terms of trade effects reported in Table 11 confirm the substantial secondary burdens involved.

The crucial issue with these calculations is the representation of aid as untied. If aid flows are smaller than commodity imports to which they are tied and if all funds are 'fungible', tying aid should have no effect.: Tied aid used to buy imports means that other domestic income is no longer used to purchase these imports and the tying of aid is ineffective. On the other hand, many complaints are voiced by LDCs about aid tying provisions, and Table 12 clearly suggests that if current aid tying provisions are binding, the potential secondary benefits to LDCs from untying aid are substantial. 
Table 12

MODEL ANALYSES OF CHANGES IN AID MECHANISMS

(1977 \$ billion)

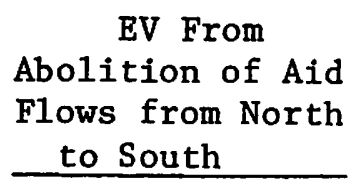

EEC

US

JAPAN

OTHER DEV.

OPEC

NIC

LDC
11.2

14.9

7.1

3.6

4.5

$-7.9$

$-45.3$
EV From Doubling of Aid

From North to South

$-13.5$

$-7.0$

$-3.1$

$-4.4$

$-10.4$

7.6

39.5
1977 Net Aid Flows

$-7.4$

$-4.9$

$-3.0$

$-2.0$

$-6.1$

2.6

20.8

Terms of Trade changes from same cases (\% change in terms of trade)

$\begin{array}{lrr}\text { EEC } & +3.9 & -3.5 \\ \text { US } & +1.8 & -1.8 \\ \text { JAPAN } & +2.3 & -2.1 \\ \text { OTHER DEV. } & +1.6 & -1.7 \\ \text { OPEC } & +3.5 & -3.2 \\ \text { NIC } & -2.0 & +1.8 \\ \text { LDC } & -11.3 & +11.1\end{array}$


VIII Conclusion

In this paper the role of trade protection policies and other features of current world trading arrangements on the North-South terms of trade are explored using a numerical general equilibrium model involving seven major world trading areas.

Results from the central case model specification suggest that a significant annual terms of trade loss is inflicted on the South through trade protection policies $L$ in the North. The welfare cost to the South is a comparable order of magnitude to the annual aid flow from the North to the South. However, trade protection in the South at much higher ad valorem equivalent rates than in the North has larger impacts on worldwide terms of trade and trade flows. A combined assessment of trade protection in the North and the South suggests that the North are net losers from worldwide trade protection and the South net gainers $\downarrow$ These results are sensitive to elasticities in the model and the elasticity sensitivity issue is explored in a number of further experiments.

Results are also reported on the role of immiserizing growth with higher growth rates of GNP (al though not of GNP per capita) in the South leading to a deterioration in the Southern terms of trade. It is estimated that after 10 years of differential growth at current growth rates, the deterioration in the terms lof trade of the South will be approximately equal to the annual terms of trade loss from protection in the North. Thus, continued differential growth performance will have long run adverse impacts on the terms of trade of the South which could be partially or wholly offset by continued reduction of trade protection in the North. Results presented from the model analysis of possible aid flow changes suggest that if aid is either untied or the tying of aid is viewed as having no binding restriction, there are significant secondary benefits associated with aid flows. The secondary benefit accrues to recipients of foreign aid. 
Bibliography

Alamgir, M. [1968] "The Domestic Prices of Imported Commodities in Pakistan: A Further Study" Pakistan Development Review, Vol. VIII No. 1 Spring 1968

Balassa, B. and M.E. Kreinen [1967] "Trade Liberalization Under the 'Kennedy Round': The Static Effects" Review of Economics and Statistics, XLTX (May), pp. 125-137

Berndt, E.R. [1976] "Reconciling Alternative Estimates of the Elasticity of substitution" Review of Economics and Statistics, Vol. 58, pp. 59-68.

Bhagwati, J. [1958] "Immis erizing Growth" Review of Economic Studies.

Bhuyan, A.R. and W. Mahmud [1979] " Domestic prices of imports: An Analysis of Trading Margins under Exchange Control" mimeo, Planning Commission, Bangladesh.

Brown F., and J. Whalley [1980] "General Equilibrium hvaluations of Tariff Cutting Proposals in the Tokyo Round and Comparisons with more Extensive Liberalization of World Trade" Economic Journal, December, Vol. 90, pp. 838-866.

Boadway, R.W. [1974] "The Welfare Foundations of Cost-Benefit Analysis" Economic Journal, pp. 926-939.

Caddy, V. [1976] "Empirical Estimation of the Elasticity of abstitution: A Review" Preliminary Working Paper OP-09, IMPACT Project, Industrial Assistance Commission, Melbourne, Australia.

Deardorff, A. and R. M. Stern [1979] "An Economic Analysis of the Effects of the Tokyo Round of Multilateral Trade Negotiations on the United States and other Major Industrialized Countries" MTN Studies No.5, prepared for the Subcommittee on International Trade, Committee on Finance, U.S. Senate, 96th Congress, Washington D.C.

Fullerton, D., J.B. Soven, and J. Whalley [1980] "Dynamic General Equilibrium Impacts of Replacing the U.S. Income Tax with a Progressive I ncome Tax" NBER Conference Paper, No. 55, October

Goldstein M. and M. S. Khan [1978] "The Supply and demand for Exports: A Simultaneous Approach" Review of Economics and Statistics, May, pp. 275-286.

Hothakker, H S and S. Magee [1969] "Income and Price Elasticities in World Trade" Review of Economics and Statistics, May, 1969

Kay, J.A. [1980] "The Deadweight Loss of a Tax gystem" Journal of Public Economics, February Vol. $13 \mathrm{pp}$. 111-121 
Kehoe, T.J. [1981] "General Equilibrium with Two Factors of Production" (mimeo, MI T )

[1980] "An Index Theorem for General Equilibrium Models with Production" Econometrica, vol. 48, pp. 1121-1131.

Kemp, M.C. [1962] "Errors of Measurement and Bias in Estimates of Import Demand Parameters" The Economic Record, pp. 369-372.

Khan, M. S. [1975] The Structure and Behaviour of Imports of Venezuela" Review i3 of Economics and Statistics, May 1975, pp.221-224

[1974] "Import and Export Demand in Developing Countries" IMF Staff Papers, November 1974, pp. 678-693.

Kravis, I.B., Kenessey, Z., Feston, A., and R. Summers [1975], A System of International Comparisons of Gross National Product and Purchasing Power, Johns Hbpkins Press.

Kreuger, A.O. [1978], Foreign Trade Regimes and Economic Development: Liberalization Attempts and Consequences, NBER, New bork.

Michaely, M. [1980] "The Terms of Trade between Rich and Poor Nations" paper No. 162, Institute for International Economic Studies, University of stockholm.

Nguyen, D.T. and A.R. Bhuyan [1977] "Elasticities of Export and Import Demand in some South Asian Countries" Bangladesh Development Studies, 1977 pp. 133-152

OECD [1979] Development Cooperation Review, OECD, Paris.

Orcutt, G. H. [1950] "Measurement of Price Elasticities in International Trade" Review of Economics and statistics, vol. 32, May, pp. 117-132.

Pal, M.L. [1964] "The Determinants of the Domestic Prices of Imports" Pakistan Development Review, vol. I v, No. 4, Winter 1964.

Piggott, J.R. and J. Whalley [Forthcoming] Economic Effects of U.K. Tax-Subsidy Policies: A General Equilibrium Appraisal, To be published by MacMillan.

Prebisch, R. [1950]"The Economic Development of Latin America and its Principal Problems" Economic Bulletin for Latin America, 1962, vol. 7, pp. 1-22 (first published as an independent booklet by UNECLA in ]950). 
Roningen, V. and Yeats, A.J. [1976]. 'Non-tariff distortions of international trade: some preliminary empirical evidence.' Weltwirtschaftliches Archiv, pp. 613-25.

Scarf, F.E., with the collaboration of T. Fansen, [1973] The Computation of Economic Equilibria, Yale University Press.

St. Hilaire, F. and J. Whalley [1980] "A Microconsistent dataset for Canada for use in Tax Policy Analysis" (mimeo, University of Western Ontario).

Shoven, J.B. and J. Whalley [1974] "On the Computation of Competitive Equilibrium on International Markets with Tariffs" Journal of International Economics, pp. 341-354.

Singer, H. [1950] "The Distribution of gains between investing and borrowing countries" American Economic Review, Papers and Proceedings, (May) vol. 70, pp. 473-85.

Spraos, J. [1980] "The Statistical debate on the Net Barter Terms of Trade Between Primary Commodities and Manufactures" Economic Journal, Vol. 90, March, pp. 107-128.

Stern, R.M., J. Francis, and B. Schumacher [1977] Price Elasticities in Internanational Trade: An Annotated Bibliography, Macmillan, for the Trade Policy Research Centre, London.

Stone, J.A. [1979] Price Elasticities of Demand for Imports and Exports: Industry Estimates for the U.S., the EEC, and Japan, Review of Economics and Statistics, Vol. LXI, May, pp. 306-312.

Taplin, G.B. [1979] "A Model of World Trade" in ed. R.J. Ball, The International Linkage of National Economic Models, North blland.

Weiskoff, R. [1979] "Trade Protection and Import Price Elasticities for Brazil" Review of Economics and Statistics, February 1979.

Whalley, J [1980], 'General equilibrium analysis of U.S.-EEC-Japanese trade and trade distorting policies. Economie Applique, Symposium issue on international trade general equilibrium models.

- [Forthcoming] Trade Liberalization Among Major World Trading Areas:

A General Equilibrium Approach, to be published by MI T press.

Yeats, A.J. [1980] Trade Barriers Facing Developing Countries, Macmillan.

[1977]. 'An evaluation of the Common Agricultural Policy as a barrier facing agricultural exports to the EeC.' American Journal of Agricultural Economics.

[1976] 'Effective protection for processed agricultural commodities: a comparison of industrial countries.' Journal of Economics and Business, pp. 3] -40 . 


\section{APPENDIX 1}

\section{Tariff Rates and Ad Valorem Equivalents of Non-Tariff Barriers} Used in the Model

The model uses ad valorem rates for tariffs and non-tariff barriers differentiated by commodity and by trading area. These are reported in Table A.1 aggregated over the separate import types by trading area. These estimates rely on literature sources which are sparse in places, and a best guess approach is used where required.

\section{A. Tariff Rates}

i) U.S.: A detailed compilation of tariff rates by commodity and trading area produced by the Special Trade Representatives Office, Office of the President, during the Tokyo Round Trade negotiations, provides the basic source. This provides information on 1976 tariff rates at a 3 digit SITC level for the U.S., both globally and bilaterally, with the EEC, Japan, Canada, and LDCs. Tariffs are available both for the U.S. and the trading partners listed on each of these trade rates. Aggregation to the model classification proceeds using 1976 imports as weights. The resulting weighted average tariffs have different rates for similar products imported from different trading areas. The impact of the generalized system of preferences (GSP) is thus captured in model tariff rates on LDC imports. Bilateral tariffs with 0 ther Developed and OPEC are set at US tariffs with the world; NICs tariffs are set at the same rates as faced by IDC imports.

ii) EEC: The same data source as for the US provides 1976 tariffs for the EEC bilaterally with the US and with the world. The tariff data are used in a comparable manner to those for the US. Bilateral EEC-Japan tariffs (not available in the data source) are assumed to be the same as bilateral EEC-US tariffs. EEC-World tariff rates are taken as the EEC-Other Developed, and EEC-OPEC rates. Rates for EEC-NIC and EEC-LDC trade are calculated from ratios by commodity of U.S. tariffs on LDC imports to US tariffs on world imports and applying these same ratios to EEC tariffs on world imports. This may slightly understate EEC tariffs on LDC imports due to differenticl application of GSP, although reduced Lomé Convention rates offset 
Table All

Ad Valorem Tariff and NTB Tariff Equivalents Used in the Mode1

A. Ad'Valorem Tariff Rates

\begin{tabular}{|c|c|c|c|c|c|c|c|c|}
\hline (SITC & $\begin{array}{l}\text { Commodity } \\
\text { code in parentheses) }\end{array}$ & EEC & US & Japan & $\begin{array}{l}\text { Other } \\
\text { Deve1. }\end{array}$ & OPEC & NIC & IDC \\
\hline 1 & $(0+1)$ & .042 & .063 & .233 & .048 & 0.0 & .500 & .080 \\
\hline 2 & $(2+4)$ & .009 & .040 & 0.0 & .036 & 0.0 & .230 & .350 \\
\hline 3 & (3) & .037 & .035 & .077 & .059 & 0.0 & .230 & .350 \\
\hline 4 & $(5,6,8,9)$ & .085 & .079 & .068 & .047 & 0.15 & .860 & .960 \\
\hline 5 & (7) & .082 & .045 & .084 & .057 & 0.15 & .860 & .800 \\
\hline 6 & (non-traded) & 0.0 & 0.0 & 0.0 & 0.0 & 0.0 & 0.0 & 0.0 \\
\hline
\end{tabular}

B. Ad Valorem Equivalents of NTBs

$\begin{array}{llcccccrr}\text { (SITC code in parentheses) } & \text { EEC } & \text { US } & \text { Japan } & \begin{array}{l}\text { Other } \\ \text { Devel. }\end{array} & \text { OPEC } & \text { NIC } & \text { IDC } \\ 1 \quad(0+1) & .332 & .438 & .721 & .497 & 0.0 & .125 & .020 \\ 2(2+4) & .485 & 0.0 & .460 & .315 & 0.0 & .058 & .088 \\ 3 & (3) & .282 & .056 & .377 & .239 & 0.0 & .058 & .088 \\ 4 & (5,6,8,9) & .079 & .075 & .081 & .078 & 0.0 & .215 & .240 \\ 5 & (7) & .017 & 0.0 & .018 & .012 & 0.0 & .200 & .200 \\ 6 & \text { (non-traded) } & 0.0 & 0.0 & 0.0 & 0.0 & 0.0 & 0.0 & 0.0\end{array}$


this to some extent.

iii) Japan: The same data source as for the U.S. is used and calculations made for Japan for 1976 tariff rates in a manner similar to that used for the EEC.

iv) Other Developed: Canada is taken as representative of 'Other Developed'. The same U.S. data source giving 1976 tariff rates is used in a manner similar to that for the EEC and Japan.

v) OPEC: Only limited information exists on trade policy regimes in OPEC countries. Descriptive information provided by the Information Office of the Saudi Arabian government indicates a $15 \%$ tariff on a range of manufactures. The assumption used is that OPEC has zero tariffs on all non-manufactured imports and $15 \%$ tariffs on manufactures. The same tariff rates apply in trade with all areas. vi) NICs: Information on nominal tariff protection by commodity in a sample of developing countries given in Balassa (1971) is used. Data on Brazil, Chile, Malaya, and Mexico from Table 3.1 are used. These data relate to trade protection in the early to mid-1960's and is therefore somewhat dated. A correspondence between the model classification and that reported in Balassa is used and an arithmetic average over these rates adopted. The same rates are used for trade between NICs and all other trade blocs.

vii) LDCs: The same source as for NICs is used (Balassa (1971) Table 3.1). Tariff data for Pakistan, and the Philippines are used in a manner similar to that above. These data arealso for the mid-1960's and are similarly dated.

\section{B. Ad Valorem Equivalents for NTBs}

In developed countries, NTBs comprise a list of both explicit and implicit trade restricting policies. Quotas, valuation practices, standards, government procurement, special import levies and seasonal restrictions are all included in such lists, which is sometimes expanded on the export side to include export credits, voluntary export restraints and other market intervention schemes.

Quantitative estimates of ad valorem equivalents of NTBs are sparse.

The procedure here is to rely on a compilation of estimates of ad valorem 
equivalents for the EEC, U.S., and Japan of NTBs by Brown and Whalley (1980) and Whalley (1980). This draws heavily on data compiled from UNCTAD sources, most notably by Yeats (1977), Roningen and Yeats (1976) and Yeats (1980). Additional source materials used are referred to in Brown and Whalley (1980). The most detailed set of estimates are those used by Whalley (1980) for a 33 commodity classification. This set of estimates is separately aggregated for the EEC, the U.S. and Japan for the six commodity model classification used here adopting trade data as weights. The same ad valorem equivalent rates by commodity for each of these three trading areas apply to their trade with all other regions. Ad valorem equivalents for NTBs in the 'Other Developed' region are taken to be the arithmetic average of ad valorem equivalents in the U.S., the EEC and Japan. In the absence of any information, and given the presumption of limited trade restriction in OPEC countries, zero ad valorem equivalents are assumed for OPEC NTBs.

For both NICs and LDCs non-tariff trade restricting policies are widely recognized as both important and significantly restrictive. Unfortunately, few studies exist which clearly document the structure of these trade restricting policies, let alone provide quantitative estimates of ad valorem equivalents. The series of NBER country studies summarized in Kreuger (1978) are helpful, but only provides small pieces of information for selected countries. The impression gained from these studies is that the major restrictive features of policies reflect (in particular) import licensing, foreign exchange rationing, and prior deposit schemes. The most complete sets of quantitative estimates of the domestic protection afforded by licences are those now available for countries in the Indian subcontinent. Pal (1965) estimated the 'scarcity premium' for imported commodities due to quantitative trade restrictions in East and West Pakistan for a selected number of commodities. Algamir's (1974) study for Pakistan takes these estimates further expanding on the number and range of commodities involved and the recent 
paper by Bhuyan and Mahmud (1979) contains estimates of trade margins created by quantitative restrictions in Bangladesh by commodity. These estimates are used here in ad valorem form for the whole LDC region aggregated from the Bhuyan and Mahmud commodity code onto the model classification. As with other trading areas, the NTB equivalents apply equally to trade with all other trading areas. Estimates of ad valorem equivalents of NTBs in NICs are sparse. For this reason, the apparent similarity of trade regimes in NICs and LDCs is used as; a defence for a rough approximation procedure. For each commodity, ad valorem equivalents for NTBs in NICs are set at the corresponding LDC NTB ad valorem equivalents multiplied by the ratio of NIC tariffs to LDC tariffs for the product involved. This procedure is based on the hypothesis that tariff and NTB protection are collinear The NTB equivalents for NICs apply equally to trade with all trading areas. 


\section{APPENDIX 2}

Summary of Principal Data Sources Used in Constructing 1977 World Benchmark Data Set

As explained in the text, a benchmark data set contains micro consistent equilibrium data in which demands equal supplies, industry costs equal industry sales, and all agents are on their respective budget constraints. In the international trade context of the present model, this involves trade and other external sector data for each bloc (inward and outward investment, dividend and interest flows, aid flows and other transfers) along with domestic production and demand data. Because the model uses the Armington assumption of product heterogeneity by trading area, the data set uses a 42-product classification ( 7 blocs each producing 6 commodities). 2 Factors of Production (capital and labour) are identified as value added contributing in each - blcc. These are immobile between trade areas and thus heterogenous across blocs. Domestic taxes and subsidies are also included in the data set along with the other data used. 1977 provides the benchmark year.

The data set constructed is a multi region analogue of the benchmark data sets recently constructed for tax policy analysis (see Piggott and Whalley (1981)), Fullerton, Shoven and Whalley (forthcoming), and St-Hilaire and Whalley (1980)). The present data set is less sophisticated in its treatment of individual trading areas, and the limitation to one consumer in each bloc considerably simplifies matters. The data are related to those used by Brown and Whalley (1980) and Whalley (1980) in their work on an earlier 4-region version of the present model. 


\section{Foreign Trade Data}

The basic sources used are:

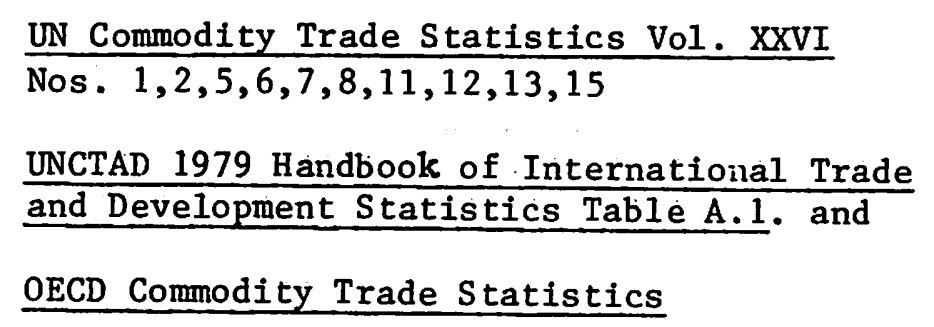

The world is initially divided into 5 areas: EEC, US, Japan, Other Developed, and Developing and recorded trade between each of these blocs for 1977 extracted using UN Commodity Trade Statistics. A separate calculation is made for each of the SITC single digit classifications (0-9) to produce a $5 \times 50$ trade flow matrix. This is then aggregated onto the model classification.
A number of problems are encountered.
(i) It is necessary to adjust

for double counting when considering trade by the EEC with the world. From trade by each individual EEC country with the world is subtracted trade within the EEC bloc. This information was taken from the 1978 OFCD Commodity Trade Statistics. (ii) It is also necessary to adjust for double counting in trade within the other Developed bloc. This is done by finding total trade between EEC, US, Japan, and 0 ther Developed and accounting for socialist trade with 0 ther Developed. This is then subtracted from trade between Developed (UN definition) and the world. This data is taken from UNCTAD 1979 Handbook of International Trade and Development Statistics Table A.I. (iii) Trade between EEC, US, Japan and Developing countries has to account for definition differences in the bloc of developing countries. The Bahamas and Netherlands Antilles are considered as Developed here but not by the UN definition.

A further breakdown in the classification into 7 trading blocs - EEC, US, Japan, Other Developed, OPEC, Newly Industrialized Countries and Less Developed Countries, follows from the 5 region data. OPEC trade is identified as that of 12 major countries - Algeria, Libya, Nigeria, Venezuela, Mexico, Trinidad and Tobago, Iran, 
Kuwait, Saudi Arabia, United Arab Emirates, Indonesia and Ecuador. Trade between OPEC and Other Developed is found by taking OPEC imports and exports with Developed Countries and subtracting OPEC imports and exports from EEC, U.S., Japan. This data was taken from UNCTAD 1979 Handbook of International Trade and Development Statistics, Table A.1, p. 660. OPEC . trade with the world was also taken from the same table.

Similar procedures were used to obtain trade data for NICs. Separate trade data are considered for Argentina, Brazil, Chile, Jamaica, Turkey, Korea, Hong Kong, Malaysia, Philippines, Singapore and Taiwan. Trade for LDCs is obtained by residual for the developing group less OPEC and NIC trade.

Further difficulties are encountered in constructing trade flow data between NICs and Other Developed, OPEC and LDCs. Since total trade with the world and 0 ther Developed has already been found, trade between 0 ther Developed and NICs and LDCs can be calculated by residual using the data on OPEC trade. Trade is split between the two blocs according to the ratio of their trade with other trading blocs. The same procedure is followed for trade between OPEC, NICs and LDCs.

2. Value Added by Industry (Taxes on Value Added)

The sources used are:

U.N. National Accounts Statistics, published 1978 Vol. I, II. Value Added data by industry from the 1973 four region trade model used by Whalley (1980), and UNCTAD 1979 Handbook of International Trade and Development Statistics. Table 6.4 
Since data are not available on the distribution of the percentage of GNP by industry for every country, Other Developed were represented by averaged data by Sweden, Norway, Australia; OPEC by Saudi Arabia, Iraq, Venezuela; NICs by Republic of Korea, Argentina and IDCs by India, Kenya, Thailand, and Zambia. Data on this distribution are taken from the UNCTAD Handbook for most recent year available. The aggregate return to capital and labour for all countries is taken from UN National Accounts for the most recent year available. These two sets of information are combined to give factor rewards in aggregate and by industry for each of the four blocs named above. The data on capital and labour return by industry are consolidated onto the model classification for the 3 advanced trading blocs from whalley (1980). These data are then scaled for consistency with the 1977 GNP at factor cost by bloc.

3. Inlermediate Transaction:s Data

The data set used by Brown and Whalley (1980) and Whalley (1980)

contains input-output transactions tables for the EEC, the U.S., and Japan for 1973. These tables are aggregated onto the classification used here and converted into coefficient form for use in the model. Coefficients from the 1972 Canadian InputOutput table used by St-Hilaire and Whalley (1980) are similarly aggregated onto the model classification and provide intermediate transactions data for the 0 ther Developed bloc. Coefficients from the 1976/77 table for Bangladesh (mimeo 1980), similarly aggregated, provide the intermediate transactions data for the less developed bloc. Constraints on resources available to the project produced a hybrid calculation for NICs and OPEC. In each case, coefficients are taken to be linear averages of dollar requirements on a cell by cell basis for LDC and Other Developed. The intermediate transactions data used by Brown and Whalley (1980) and Whalley (1980) contain import requirements separated from domestic product requirements. For the other regions, disaggregation of 'total' coefficients into 'domestic' and 'import' coefficients uses the ratio of imports to domestic production for the product input involved. 
The intermediate transactions data thus assembled provide the basic input data to the calibration process for the CES intermediate requirements functions in the model.

\section{Final Demand Data}

Unlike the more detailed individual country data sets constructed by the authors mentinned earlier, there is little detail on the demand side in each of the separate bloc data sets in the present data compilation. The model only considers one single consuming agent in each bloc, simplifying the calculation of final demand data. For domestic products, final demands are equal to gross output less domestic intermediate requirements less exports; for imports,final demands equal import values. Iess intermediate uses. These final demand data then provide the starting point for the calibration calculation of parameters in the CES final demand functions.

\section{Foreign Aid Flows}

The model incorporates foreign aid flows between blocs. The main source used is the OECD Development Cooperation Review (1979) p. 210-211, Table A.12. Total outflow and official flows for the following donor countries are used: Australia, Austria, Belgium, Canada, Denmark, Finland, France, Germany, Italy, Netherlands, New Zealand, Norway, Sweden, Switzerland, U.K., U.S. and Japan. Figures for the EEC are divided between each of the EEC countries according to their population ratios. Figures for recipient countries are taken from the 1979 OECD Review, Table D.2, p. 244-45. Figures are of Official Development Assistance (ODA) from all sources. Total aid inflow (ODA) is adjusted to equal aid outflow (Total Official Flows) because ODA (Official Development Assistance) includes OOF (Other Official Flows). 
6. New Debt Issue and Debt Service

Debt service also enters external sector transactions. The main sources used are UNCTAD 1979 Handbook of International Trade and Development Statistics. Table 5. 13, p. 446-453, Development Cooperation Review (75-76) p. 203-205 Table 9.10 1978: Table A. 11, 12, p. 201-202. Debt transactions are divided between debt outstanding and debt service. To find the debt holders, figures for development lending and capital and private flows were added up for the years 1973-77 for each of the following countries: Australia, Austria, Belgium, Canada, Denmark, Finland, France, Germany, Italy, Japan, Netherlands, New Zealand, Norway, Sweden, Switzerland, UK, and US. Data on debt outstanding and debt service are taken from Table 5.13.

\section{Other Capital Flows}

A residual capital flow transactions matrix is used to balance external sector transactions. Deficit countries are importers of foreign capital, surplus countries are exporters of foreign capital. A simple closure procedure of producing a 'minimally' consistent matrix is followed. Capital purchases by capital importers form part of the CES demand system of importing regions; capital flows are thus endogenous to the model. 
$\underline{1981}$

\begin{abstract}
8101C Markusen, James R. Factor Movements and Commodity Trade as Compliments: A Survey of Some Cases.

8102C Conlon, R.M. Comparison of Australian and Canadian Manufacturing Industries: Some Emplrical Evidence.

8103C Conlon, R.M. The Incidence of Transport Cost and Tariff Protection: Some Australian Evidence.

$8104 \mathrm{C}$ Laldler, David. On the Case for Gradualism.

$8105 \mathrm{C}$ W1rick, Ronald G. Rational Expectations and Rational Stabilization Policy in an Open Economy.

8106C Mansur, Ahsan and John Whalley Numerical Specification of Applied

General Equilibrium Models: Estimation, Calibration, and Data.

8107C Burgess, David F., Energy Prices, Capital Formation, and Potential GNP

$8108 C$ DSU Jimenez, E. and Douglas H. Keare. Housing Consumption and Income in the Low Income Urban Setting: Estimates from Panel Data In El Salvador

8109 C DSU Whalley, John Labour Migration and the North-South Debate

$8110 \mathrm{C}$ Manning, Richard and John McMillan Government Expenditure and Comparative Advantage

$8111 \mathrm{C}$

Frled, Joel and Peter Howltt Why Inflation Reduces Real Interest Ratess
\end{abstract}

$\underline{1982}$

8201C Manning, RIchard and James R. Markusen Dynamic Non-Substitution and Long-Run Production Possibilities

$8202 \mathrm{C}$

Feenstra, Robert and Ken Judd Tariffs, Technology Transfer, and Welfare

8203C Ronald W. Jones, and Douglas D. Purvis: International Differences in Response to Common External Shocks: The Role of Purchasing Power Parity

$8204 \mathrm{C}$ James A. Brander and Barbara J. Spencer: Industrial Strategy With Committed Firms.

8205C The North-South Debate and the Terms of Trade: An Applied General Equilibrium Approach

8206C Capital Ut1lization in General Equilibrium

8207C On the Estimation of Import and Export Demand Elasticities and Elasticity Pessimism 